\title{
OTROS PUNTOS DE ENCUENTRO: NEOPOPULARISMO Y POESÍA SOCIAL DEL GRUPO DEL 27 EN LA POESÍA DE EUNICE ODIO
}

\author{
RONALD CAMPOS LÓPEZ \\ Universidad de Costa Rica \\ ronald.camposlopez@ucr.ac.cr \\ ORCID: 0000-0001-5168-8392
}

\section{RESUMEN}

Este artículo continúa la labor hermenéutica y comparativa de estudiar los legados vanguardistas del Grupo del 27 en la poesía de la costarricense Eunice Odio. Se analizan cinco poemas de esta autora, a fin de establecer sus diálogos con textos del 27, en relación con el neopopularismo y la poesía social. Se concluye que, por un lado, el neopopularismo odiano se dirige a dos cuencas: 1) la recuperación de la figura del negro de la tradición cubana y latinoamericana, con el fin de denunciar la marginalidad, injusticias sociales y laborales, llanto, dolor y tragedia que padece, tanto como el gitano en el cante jondo andaluz; 2) la reelaboración de pasajes o personajes bíblicos y similitudes retóricas y formales con algunos de los poemas navideños del 27. Por otro lado, la poesía social odiana se enfoca en la coyuntura de la guerra civil española, la cual defiende como el 27 la Segunda República, se solidariza con esta lucha política, exalta a los milicianos como figuras heroicas del conflicto, se identifica con las víctimas, y denuncia al bando sublevado y la destrucción que este provocó en el país.

PALABRAS CLAVE: poesía costarricense, poesía española, vanguardia, Eunice Odio, Grupo del 27.

\section{OTHER MEETING POINTS: THE GROUP OF 27'S NEOPOPULARISM AND SOCIAL POETRY IN THE EUNICE ODIO'S POETRY}

\section{ABSTRACT}

This paper continues the hermeneutical and comparative work of studying the avant-garde legacies of the Group of 27 in the poetry of the Costa Rican Eunice Odio. Five poems of this author are analyzed, in order to establish his dialogues with texts from 27's Spanish writers, related to neopopularism and social poetry. It is concluded that, on the one hand, Odian neopopularism addresses two basins: 1) the recovery of the figure of the black of the Cuban and Latin American tradition, in order to denounce the marginality, social and labor injustices, tears, pain and tragedy that it suffers, as much as the gypsy in the Andalusian cante jondo; 2) the reworking of biblical passages or characters and the rhetorical and formal similarities with some of the Christmas poems of the 27. On the other hand, Odian social poetry focuses on the conjuncture of the Spanish Civil War, which defends as the 27 the Second Republic. It is in solidarity with this political struggle. It exalts the militiamen as heroic figures of the conflict. It identifies with the victims and denounces the rebellious side and the destruction it caused in the country.

KEYWORDS: Costa Rican poetry, Spanish poetry, vanguard, Eunice Odio, Group of 27. 


\section{CONTINUACIÓN DE UNA LABOR}

En un estudio anterior, Campos (en prensa) presenta escasas menciones o pocos abordajes sobre los puntos de encuentro que críticos como Baeza Flores (1953, 1978), Díaz-Casanueva (1975), Liscano (1975), Monge (1992), Cervera (2001) y Pleitez (2012) establecen entre la poesía de la costarricense Eunice Odio y la de miembros del Grupo del 27,1 como Rafael Alberti, Pedro Salinas, Vicente Aleixandre o Federico García Lorca. Ante los vacíos de estos trabajos, Campos (en prensa) propone, entonces, como tesis de investigación estudiar, en la poesía y la ensayística de Odio, legados vanguardistas del Grupo del 27, específicamente, realizaciones estéticas de la poesía pura, el gongorismo, el neopopularismo y la poesía social, más allá del surrealismo que la crítica literaria —verbigracia: Baeza Flores (1953, 1978), Burdiel de las Heras (1987), Vallbona (2001), Santos Silva (2001), Pleitez (2012) o Rojas y Ovares (2018) — insiste en señalar en la poesía odiana.

Sin embargo, por la extensión del trabajo, no fue posible exponer todos los resultados del análisis literario; por lo cual se decidió dar a conocer, primeramente, los legados de la pureza y el gongorismo, con base en 7 poemas y 2 ensayos de Odio.

Entre las conclusiones, se pudo establecer que la poesía pura se manifiesta en tres gradaciones distintas — cuyos límites se difuminan entre sí-en los textos poéticos odianos: 1) una perspectiva fenomenológica conseguida a partir de la deshumanización del arte según Ortega y Gasset (1999); 2) una manifestación del suprarrealismo que, en diálogo con el Cubismo, el Creacionismo y la deshumanización orteguiana, implica la desrealización y la pro-moción de metáforas puras y la realización de la irrealidad; 3) la eutrapelia, basada en el juego poético que pretende la inmanencia y el encanto verbal, pero también la farsa ante el arte nuevo. La primera gradación se observa en «En la tarde, en las ramas», «Alizarín (Canción)» $\mathrm{y}$ «Los álamos de la tarde»; la segunda, en «La clase de matemáticas», «Alba» $\mathrm{y}$ «A Natalia, la niña del pintor Granell»; y la tercera, en «De un poema con cuatro acentos».

El desarrollo de algunas ideas relativas al gongorismo se encuentra en los ensayos «Nostalgia del paraíso»y «En defensa del castellano». El yo discursivo recupera del mismo modo que los del 27 la figura del poeta áureo cordobés para: 1) remarcar la poesía como un arte solo de unos pocos que logren contemplar intelectivamente las metamorfosis del ser de las cosas y su trascendencia artística; 2) legitimar la incomunicación poética en medio de una búsqueda de un lenguaje inusual, difícil, pero claro, que violente los esquemas discursivos tradicionales de la poesía y el convencionalismo de las imágenes poéticas fosilizadas en el lenguaje, con el propósito de pro-mover la estilización y la consecución de la

\footnotetext{
${ }^{1}$ La discusión entre las denominaciones «generación» o «grupo» del 27 es conocida y extensa. Sin entrar en detalles de esta, y dado que ocuparía un espacio no pertinente a este estudio, queda claro que en este trabajo se prefiere la segunda denominación.
} 
poesía pura; 3) evidenciar la sustitución, el antirrealismo y la belleza estética inmanentes de la metáfora gongorina; 4) exaltar el carácter des-emocionado de la poesía, a fin de darle cabida al pensamiento; 5) defender el Creacionismo, en cuanto que horizonte poético y artístico que nutre la poesía pura y, por ende, el gongorismo; 6) rechazar el uso del lenguaje literario en la narrativa, puesto que es incompatible con la exigencia de la síntesis imaginaria y lingüística que persigue la poesía vanguardista; 7) proponer a Góngora como el maestro y ejemplo de la imaginación idiomática, gracias a la cual se logra revitalizar musical e imaginariamente el lenguaje, más allá de sus cualidades pragmáticas y conceptuales. El juego con la sintaxis barroca como soporte de imágenes vanguardistas (creacionistas, puras o suprarreales) se observa asimismo en el poema «Alba».

Finalmente, se evidencian en los textos odianos diálogos con las vanguardias latinoamericanas, del mismo modo que los textos del Grupo del 27 dialogaron con estas. Sirvan, por ejemplo, los casos del Creacionismo huidobriano, nutriente necesario del suprarrealismo de Odio y del 27; y de la metafísica del lenguaje leída con respecto a las Soledades de Góngora, por parte de Reyes (1910, 1928), mucho antes que los poetas del 27. Estos aportes permiten visualizar las coincidencias y alcances de esa comunidad de poetas que, en medio de esa ambición de concebir proyectos poéticos de ruptura, conformaron, por separado y en conjunto, una revolucionaria estética del lenguaje: pro-mover una labor artística integral, en la que la poesía se atiene a su propia lógica formal, estilizada; una lógica que responde a la hiperconciencia que busca una estética centrada en su propia materia y el dinamismo del lenguaje.

Con base en esa muestra textual estudiada, se logró demostrar que Odio comparte con autores y autoras del Grupo del 27 la misma profunda vocación literaria: el afán de alcanzar la originalidad y perfeccionamiento poéticos, gracias al esfuerzo y la rigurosa reflexión sobre el lenguaje, a fin de extraer de él las mayores posibilidades expresivas y provocar, por consiguiente, que el hecho literario se convirtiera en un lugar de encuentro dinámico entre el poeta, el poema y el lector; esto es, entre el artista; la materialización formal, intelectual, autónoma, inmanente, trascendental solo en sí misma, suprarreal; y la persona invitada a ejecutar la epojé y a contemplar la transmutación fenomenológica del ser tanto de las sustancias artísticas, como de sí misma. Todo esto a través de las formas poemáticas e imágenes innovadoras, vivas, frescas, móviles, seductoras, retadoras, que permiten por igual la elevación del creador, la palabra (el lenguaje) y las experiencias estéticas, especialmente pro-movidas por la belleza intelectual (Campos, en prensa).

Con miras, pues, a completar el panorama de los legados vanguardistas del 27 en la poesía de Odio, en esta segunda entrega, se propone continuar la exposición de las huellas del neopopularismo y la poesía social, a partir de 5 textos. Cuatro corresponden a poemas dispersos: «Nube y cielo mayor» y «Pepón 
de la Campa», publicados en 1946, en Repertorio Americano; "Zafra», en 1946, en Antología de poetas costarricenses; ; y «Navidad», en 1947, en el periódico guatemalteco El Imparcial. ${ }^{4}$ Uno pertenece a Territorio del alba y otros poemas (1974): se trata de «Huida de San José, el niño y la virgen».

Basado en esta muestra textual, se procede a dividir el siguiente análisis literario en los dos apartados pendientes, dedicados a demostrar la otra mitad de la tesis inicial: por un lado, las manifestaciones del neopopularismo; por otro, las de la poesía social.

\section{NEOPOPULARISMO}

Con respecto a los ecos del neopopularismo del 27 en los poemas de Odio, se pueden identificar dos vertientes: una que claramente dialoga con la regionalización de las vanguardias latinoamericanas; otra asociada principalmente con el tema de la natividad.

\section{1. ¿UN CANTE JONDO POR LOS NEGROS CUBANOS?}

En relación con la primera vertiente, Monge (2005) recuerda que, durante la regionalización de las vanguardias en América Latina, estas manifestaron un carácter nacional y continentalista relacionado «con el creciente papel de las preocupaciones políticas y culturales en favor de sus países, y por parte de los escritores» (92).

En esta dirección, evóquese, por ejemplo, el negrismo en la poesía vanguardista del cubano Nicolás Guillén. Esta contraría la estética modernista y la tradición europea mediante una simbiosis de lo primitivo, el folklore y cultura afroantillanos y lo moderno, de lo mestizo y lo afrodescendiente, con el propósito no solo de defender una cultura multirracial y la unidad de los pueblos divididos por prejuicios racistas (Oviedo 2001), sino también de romper con la permanencia de un mundo postcolonial y feudal (Veres 2002). Por eso, desde Motivos de son (1930), la poesía de Guillén se orienta tanto a reclamar los derechos de los negros, así como a criticar a la oligarquía y clases dirigentes ante la discriminación y explotación del negro y el mulato en Cuba (Veres 2002).

Esta referencia es necesaria para comprender el poema «Zafra», de Odio:

Zafra del negro en la sombra,

zafra del negro llorando,

Dorada zafra escondida,

en la sangre renegrida

por la pena que se va:

\footnotetext{
2 En número 20, tomo XLII, año XXVI, número 1008, pp. 310-311 (Odio 2017, 2018).

${ }^{3}$ Pp. 165-168 (Odio 2017). Paldao y Vallbona (Odio 2018) solo recogen los tres primeros poemas.

${ }_{4} 24$ de diciembre (Odio 2017).
} 


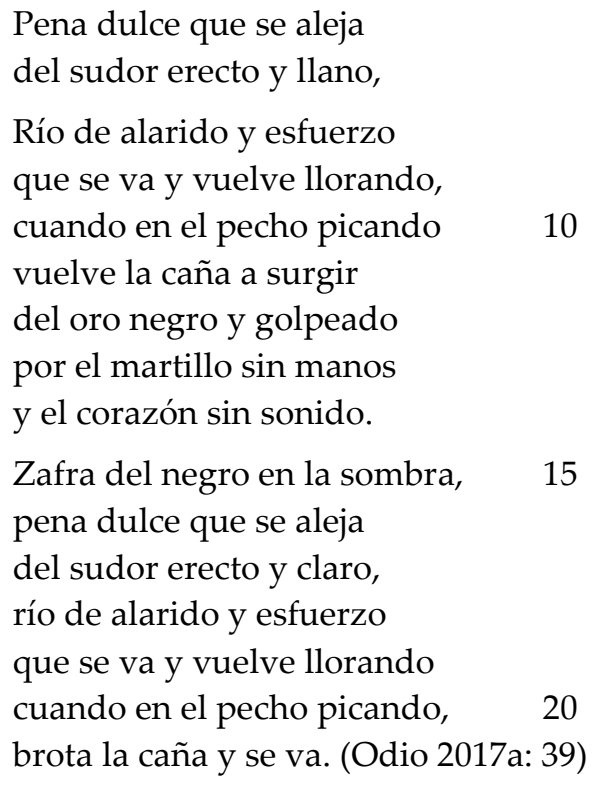

En él se enuncia justamente la exclusión social, invisibilización, soledad y la tragedia a que se ve reducido el negro en la zafra. Esta se representa como un espacio de trabajo forzado, cansancio, desgaste, dolor y angustia, donde el negro permanece recluido hasta el punto de que llega a interiorizarlo como el espacio al que pertenece (vv. 1-5). Esta explotación laboral cotidiana en la zafra llega a dejar al negro sin expresión (vv. 6-7) y a subsumirlo en una rutina cada vez más trágica, hasta el punto de reificarlo, consumirle su vitalidad, su humanidad y aniquilarlo (vv. 8-14). La zafra es condensada, en la base-afirmación del modelo compositivo sintético del poema, ${ }^{5}$ como un ámbito de exclusión y rechazo social, explotación, tortura, deshumanización — no se entienda este término según Ortega y Gasset (1999), sino como privación del carácter humano-y muerte. Esta construcción es reforzada por el simbolismo nictomorfo (Durand 1982) de la «sombra» y la reiteración de los versos 1, 6-10.

El poema «Zafra», en síntesis, convoca la tradición neopopular cubana y, lo mismo que la poesía de Guillén, saca del olvido a aquella porción explotada de la ciudadanía cubana (Veres 2002), pero también a una voz cultural más de América Latina. En este sentido, «Zafra» y Motivos de son coinciden en propósito, tal y como lo dejan ver las palabras del propio Guillén al referirse a su poemario:

Mis poemas-sones me sirven además para reivindicar lo único que nos va quedando que sea verdaderamente nuestro, sacándolo a la luz, y utilizándolo como elemento poético de fuerza. [...] en lo que se refiere a la orientación de mi poesía, creo que al fin me he encontrado. Me encanta el estudio del pueblo. La búsqueda de su entraña profunda. La interpretación de sus dolores y sus goces. (Guillén 1990: 62-63)

\footnotetext{
${ }^{5}$ Según López-Casanova (1994), un modelo compositivo sintético se articula cuando se parte de unidades explicativas y de carácter condensador hacia una base-afirmación ubicada al final del texto.
} 
La pregunta ahora es ¿cómo se relaciona lo anterior con el neopopularismo del 27? Recuérdese que Juan Ramón Jiménez influyó en Alberti, García Lorca y Gerardo Diego con respecto al gusto y afición por la poesía popular (García 2016). A través de estos, poco a poco el Grupo se abocó a la recuperación de cualquier expresión del folklore y lo popular (por ejemplo, cancioneros y romanceros tradicionales, canciones de Gil Vicente y Lope de Vega, cantares vivos del pueblo, entre otros). Por eso, se manifestó una afición por formas y ritmos (romances, seguidillas, canciones, villancicos, estribillos) y recursos estilísticos (repeticiones, paralelismos, diminutivos) propios de la poesía tradicional. El regreso a la tradición poética española se vincula, por consiguiente, con la intencionalidad y deseo de las vanguardias de cantar la forma pura, sin estar sujetas a las convenciones del mundo moderno. Así pues, el nuevo artista no niega lo anterior, más bien lo integra; porque el poeta — según los del 27- no destruye, sino que crea; ${ }^{6}$ no combate: construye. A propósito de esto, considérese la defensa de la poesía tradicional y la vuelta a la estrofa, hecha por Diego $(1927,1928)$. La recuperación, entonces, del folklore y lo popular - de esa tradición sin letra, a como la llama Salinas (1983) — se ve revestida de los logros de la poesía pura y el gongorismo que ya los miembros del 27 habían ejecutado con precisión y exitosamente, de manera que el tema y las formas tradicionales se sintetizaban con las imágenes vanguardistas.

Mientras los del 27 recuperan la tradición española, Odio retoma, como se ha dicho, al igual que Nicolás Guillén, la figura del negro como parte de lo folklórico y popular cubano y latinoamericano, a fin de denunciar el olvido en que este vive y las injusticias sociales y laborales que padece. Para ello, Odio compone una canción, no siguiendo ninguna forma estrófica o poemática castellana, pero sí creando estrofas en las que se mantienen rimas asonantes gemelas —en la primera, de /ia/ en vv. 3-4; en la segunda, de /ao/ en vv. 9-10 y vv. 12-13; y en la tercera también de /ao/ en vv. 19-20, del v. 17 que se uniría libremente al conjunto rítmico-; empleando figuras de repetición - la conversión (vv. 1-2, 7 y 17), el paralelismo (vv. 1 y 15, 6-7 y 16-17, 8-10 y 18-20), la epífora (vv. 2, 9 y 19), la repetición diseminada de «zafra», «negro», «sangre», «pena», «caña»; y basándose en el isosilabismo octosilábico propio del ritmo popular. Obsérvese que, en este esfuerzo neopopularista, Odio vivificaría la tradición formal, según lo entiende Salinas:

Es necesario que el poeta, haciendo suya la tradición, vivificándola en él mismo, la modifique según la experiencia que le depara su propio existir, en el cual entra la novedad, y así se combinan ambos elementos. Hay épocas en que el elemento tradicional es más fuerte que la novedad, y son épocas académicas; hay otras en que la novedad es más fuerte que la tradición, y son épocas modernistas. Pero solo por la vivificación de la tradición al

\footnotetext{
${ }^{6}$ Esta fue una de las razones por las cuales los integrantes del Grupo del 27 se diferenciaron y desligaron de los poetas ultraístas, a quienes acusaron de fallidos por haberse abocado a ciegas a las imágenes vanguardistas, sin considerar la tradición castellana, olvidando la tradición de las formas, renegando de ella; destruyéndola.
} 
contacto de la novedad, ambas en proporción justa, pueden surgir obras que sobreviven a su época. (Salinas 1983: 374)

En el nivel del contenido, préstese atención a cómo la zafra se construye como un espacio de dolor, angustia y llanto, donde el negro está sometido siempre a un destino trágico. Para ello se emplean metáforas puras (vv. 8-9, 1819), la topografía (vv. 1-4) y el hipérbaton (vv. 10-14), los cuales permiten leer huellas de la poesía pura y del gongorismo aprendidos por Odio (Campos, en prensa), aunque no exentos de cierta impureza, debido a las marcas de emotividad que figuras patéticas como la hipérbole del dolor y la prosopopeya de la pena inscriben necesariamente en el texto, con el propósito de conmover al lector y de que la crítica contra esta violencia y sufrimientos humanos sea significativa y resuene en los receptores.

Esta misma configuración de la zafra se encuentra, mutatis mutandis, en Poema del cante jondo (1921). ${ }^{7}$ En vez de la zafra y los negros, se presentan la «Andalucía del llanto» y los gitanos (García Lorca 2013: 263). La canción negra de Odio es análoga al cante jondo andaluz, en tanto que ambos, a partir de una tradición milenaria de raíz oriental - africana para el poema de Odio; hindú, persa y árabe para el poemario de García Lorca-, trazan una geografía trágica o del llanto. Al igual que García Lorca exalta cómo el cante jondo «lleva en sus notas la desnuda y escalofriante emoción de las primeras razas orientales» (2017: 4), así Odio - y también Guillén- desnuda en su poesía negra el dolor del abuelo negro, a como lo llama Rojas Mix (1997). En las poéticas lorquiana y odiana, el vitalismo radica en la conciencia trágica del gitano y el negro, respectivamente. Podría afirmarse, pues, que tanto en el poema de Odio como en los de García Lorca, al decir de este último, «la Pena se hace carne, toma forma humana y se acusa con una línea definida» (2017: 17); ambos textos se constituirían —al decir de Ortega (1986) — como expresiones telúricas de pueblos que han sido aislados social y geográficamente, cuya música viene a representar la memoria cultural de su pasado colectivo. ${ }^{8}$

Por ejemplo, en «Poema de la soleá», se describe, análoga a la zafra, la andaluza como una tierra donde una pena negra se cierne constantemente sobre sus habitantes y los hiere («Tierra/ de la muerte sin ojos/ y las flechas», García

${ }^{7}$ Aunque en este análisis se enfatiza la presencia de este universo trágico en Poema del cante jondo, dicho mundo se extiende en cierta medida hasta Romancero gitano (1924-1927), como bien lo evidencia la base-afirmación en el modelo compositivo sintético del «Romance de la pena negra»: «¡Oh pena de los gitanos!/ Pena limpia y siempre sola./ ¡Oh pena de cauce oculto/ y madrugada remota» (García Lorca 2013: 379).

8 Hay que señalar que la denuncia de la esclavitud del negro es explorada por García Lorca sobre todo en Poeta en Nueva York, pero desde una perspectiva surrealista, la cual permite atacar los fundamentos ideológicos del mundo capitalista y el poder hegemónico del blanco sobre el negro. Por eso, Lorca en este poemario dialogaría con el movimiento de la negritud del poeta haitiano Aimé Césaire, pues aquel se solidariza con el negro norteamericano, rechaza la cultura colonialista y rescata al negro como depositario de la expresión cultural (Ortega 1986). 
Lorca 2013: 262-263). La cancioncilla de Odio, entonces, evocaría el mismo llanto que la siguiriya, en el poema «La guitarra», arroja malherida, y por lo que «Es inútil/ callarla./ Es imposible/ callarla» (García Lorca 2013: 259). En el poema odiano, el grito de un negro en la zafra es el grito de todos los negros que en condiciones afines también sufren; el suyo es el grito de dolor, de protesta humana; del que muere; por eso, paraliza, ya que el grito es el resultado de una violencia ejercida y vivida. Se trata, pues, de un grito colectivo que va de zafra en zafra, tanto como aquella «elipse de un grito,/ [que] va de monte/ a monte» (2013: 259), en «El grito», de García Lorca.

Finalmente, la colectividad negra recluida y condenada a padecer en la zafra una rutina y un destino trágicos recuerdan a aquellos hombres del poema lorquiano «Pueblo», atrapados en un destino igualmente de dolor, llanto y muerte sin término. Así, tanto la zafra como la tierra andaluza se construyen como «un calvario»:

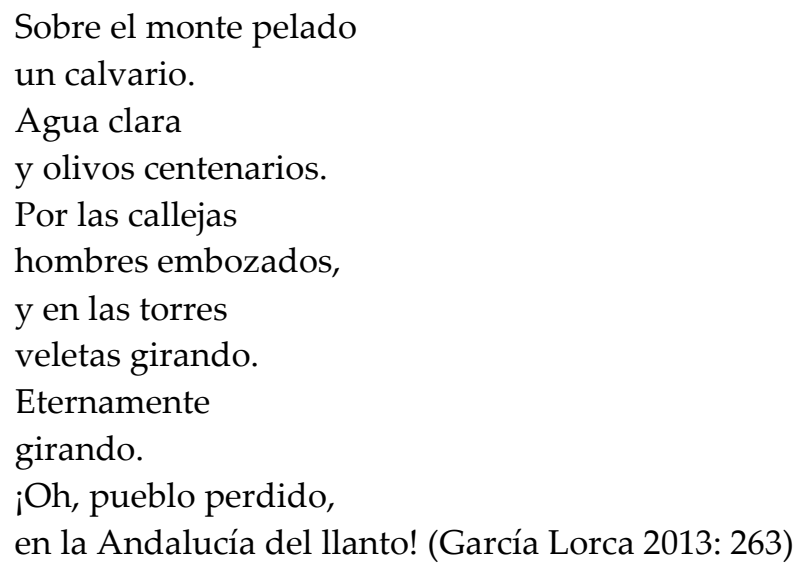

Ortuño (2014) señala que al menos cuatro mitos cristianos - la palabra creadora, el paraíso perdido, el Cristo-Prometeo y el poeta-profeta- aparecen, transversalmente y desde una perspectiva romántica, a lo largo de las producciones literarias del Grupo del 27. En relación con el tercer mito, suele aparecer el mitema del monte de los Olivos o Getsemaní, a fin de representar, en cuanto que símbolo de miedo, soledad y muerte, los lugares de sufrimiento espiritual y antesala del padecimiento físico. Dicho mitema se observa claramente no solo en «Pueblo», sino también en «Zafra», ya que en ambos poemas los espacios del gitano y el negro se construyen simbólicamente como un lugar de pasión.

Además de la comparación anterior, la zafra del poema odiano se homologaría a la «Cueva», espacio de reclusión de los gitanos, del que únicamente se escuchan brotar sollozos, sangre y sufrimiento. Tanto los negros como los gitanos representan en sendos poemas esa población marginada que, en su soledad colectiva y existencial, padecen, según evidencian los textos, únicamente la pena y fatalidad. Dicen los primeros doce versos del poema lorquiano: 


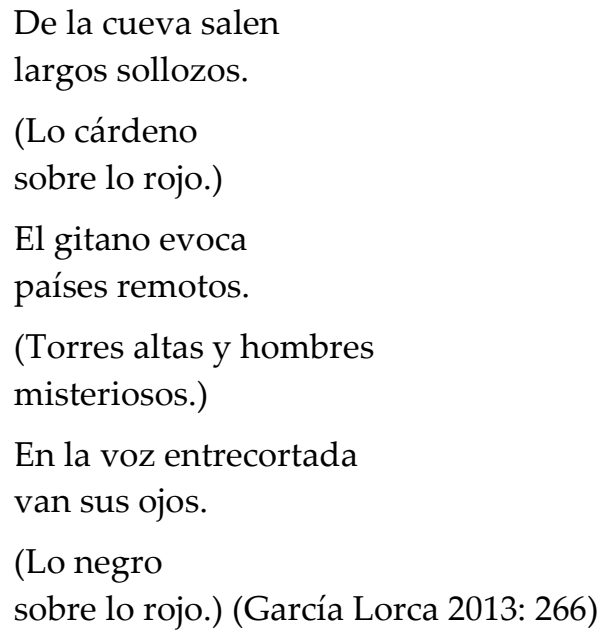

Los incisos anotados entre paréntesis constituyen gestos que evidencian la función ideológica de la voz lírica. ${ }^{9}$ Obsérvese que en tales incisos se encuentran huellas de las enseñanzas cubistas, que poetas del 27, como García Lorca, aplicaron en parte de sus primeros textos vanguardistas. Tales enseñanzas se orientan a conseguir formas y volúmenes definidos y estilizados, como en el segundo inciso; pero también a emplear colores básicos primarios, como el rojo o el negro, y secundarios, como el púrpura. Simbólica e ideológicamente, estos colores y su combinación en el poema no son gratuitos. En el primer inciso, el color «cárdeno» evoca la muerte; mientras que el «rojo», la sangre, la vida (Chevalier y Gheerbrant 1988). La superposición de aquel color sobre este representaría el dolor, las heridas, acaso la necrosis, de aquellos gitanos cuya sangre se derrama y que, por tanto, sufren mortalmente en la «Cueva». El resultado cromático es un rojo violáceo; símbolo, entonces, de la pena y la fatalidad.

En el tercer inciso, el color negro, símbolo del «estado de muerte consumado» (Chevalier y Gheerbrant 1988: 747), se sobrepone ahora al «rojo»; de modo que la combinación cromática crea el marrón o pardo, «el color de la gleba, de la arcilla, del suelo terrestre. Recuerda también la hoja muerta, el otoño, la tristeza. Es la degradación y el mal casamiento de los colores puros» (803). El marrón, por ende, representa la degeneración y aniquilación física y psíquica de los gitanos, su sepultura y desaparición total. En este color pardo desencadena el rojo violáceo del segundo inciso.

Nótese, en fin, cómo estos incisos inscriben la función ideológica de la voz con respecto a los gitanos. Estos mismos valores negativos podrían ser extrapolados, sin duda alguna, al poema de Odio, ya que no solo el ambiente de la zafra como la cueva son lugares de pasión; sino que también, mediante el sintagma prepositivo «en la sangre renegrida», se puede leer igualmente el dolor,

\footnotetext{
${ }^{9}$ Según López-Casanova (1994), esta función se manifiesta cuando el hablante lírico, en cuanto que sujeto modalizador, se implica mediante gestos ideológicos; por ejemplo: una narratividad, ironías, comentarios, aclaraciones, matizaciones, reflexiones, incisos, entre otros.
} 
la degeneración integral, la muerte y la desaparición de los negros. Además, como apunta Campos (en prensa), en la poesía de Odio se observan claramente las enseñanzas del Cubismo con respecto a la creación pura de los objetos estéticos, si se consideran aquella metáfora pura y topografía señaladas más arriba.

\subsection{Aire de Villancicos}

Pasando a otro motivo del neopopularismo abordado por el Grupo del 27, cítese ahora la natividad de Jesús. Este tema es recurrente, desde ópticas y estilos diferentes, por ejemplo en «Navidad», de Alberti; «San Gabriel (Sevilla)» y «Nacimiento de Cristo», de García Lorca; «Letrilla de la Virgen María esperando la Navidad», «Villancico del rifador», «Canción al Niño Jesús» ${ }^{10} \mathrm{y}$ «[Quién ha entrado en el portal]», de Diego; «Navidad» y «Belén», de Jorge Guillén; «La Navidad preferida (Belén malagueño)», de Aleixandre; «En todo nacimiento repican campanas de Navidad», de Alonso; «Nochebuena cincuenta y una», de Cernuda (Carratalá 2005); y «Nochebuena triste» y «(Navidad)», de Champourcín (1991).

De este conjunto, los textos de Alberti; «Canción al Niño Jesús» y «[Quién ha entrado en el portal]», de Diego; los tres de Guillén y el de Aleixandre se relacionarían con el poema «Navidad», de Odio; mientras que la parte «Víspera de la huida a Egipto» del texto de Alberti y «San Gabriel (Sevilla)», de García Lorca, se vincularían con el otro poema de Odio: «Huida de San José, el Niño y la Virgen».

Desde el epígrafe, la «Navidad» de Odio dialoga con la tradición popular del siglo XVI, pues se toman unos versos de un villancico anónimo: «Esta noche es nochebuena,/ no la debemos dormir...» (2017a: 50). Desde aquí, el hablante lírico (re)construye la escena del portal de Belén, con las figuras características de la estampa navideña (los pastores, la Virgen, el Niño, José, los ángeles).

En cuanto al espacio, la topografía en el poema de Odio presenta un río cercano al portal («El agua rompe en las piedras/ su cabellera de vidrio», 2017a: 50). Este mismo motivo se observa tanto en «Belén» («Se oye un rumor de manantial», Carratalá 2005: 28); así como en «La Navidad preferida», poema en que el sujeto lírico recuerda su infancia en Málaga y cómo confeccionaba el portal con distintos materiales, entre ellos, vidrio para simular el agua («La mano del niño/ sapiente, un instante/ del vidrio hacía agua», Carratalá 2005: 31). Tanto en «Belén», como en «Navidad» de Odio, el portal aparece como un lugar de regocijo y garantía de un futuro esperanzador («Aquellos reyes de paz/ ¿Qué dieron a tu niñez?/ ¿Qué pesaba en tu balanza?/ - La esperanza», Carratalá 2005:

\footnotetext{
${ }^{10}$ En Carratalá (2005) este poema está incompleto: le falta la tercera estrofa. En la antología de Lama (1997), dicho poema aparece con el título «La palmera».
} 
29; «esta noche es nochebuena,/ no la debemos dormir!/ La noche duerme en el campo/ coronada de luceros», Odio 2017a: 51).

El hablante lírico odiano llama con alegría a los pastores a que lleguen al portal; así permiten leerlo tanto la exclamación como la epanadiplosis: «jVenid pastores, venid» (2017a: 50). Esta invocación es tomada del villancico «Venid, pastorcillos» («Venid, pastorcillos,/ venid a adorar/ al Rey de los cielos,/ que ha nacido ya»); y se escucha igualmente tanto en «Belén» («Acude un pastor a un portal», Carratalá 2005: 28); como en «Nochebuena cincuenta y una», texto en los cuales los pastores y Reyes Magos contemplan en el Niño el mensaje de amor que redimiría al mundo profano y caótico, encanallado por el odio, la perfidia y la hipocresía («Velad pues, pastores;/ adorad pues, reyes,/ su sueño amoroso/ que el mundo escarnece», Carratalá 2005: 35).

En una parte de la prosopografía odiana de la Virgen se enuncia: «Que María está coronada/ de sombra, miel y alhelí» (2017a: 50). Este último símbolo se puede visualizar específicamente de color blanco, ya que anteriormente son también blancos los otros adornos de la Virgen $\mathrm{y}$, además, en dicho símbolo resuena el hecho de que la «Navidad», de Alberti, pertenece a la sección «El blanco alhelí» en El alba del alhelí (1925-1926). Considerando estas coordenadas, dicho alhelí representaría en el texto de Odio la paz y la humildad de la Virgen.

En cuanto a la prosopografía del niño Jesús, tanto en el poema de Odio («Que el niño es de oro en capullo», 2017a: 50) como en «Canción al Niño Jesús» se comparte la metáfora del capullo para describir a aquel encerrado en sí mismo mientras duerme o con deseo de descansar protegido por su madre («que lo que quiere es dormirse/ y es, capullito, cerrarse/ para soñar con su madre», Lama 1997: 167). Tanto en el poema de Odio como en «Navidad», de Guillén, se describe al Niño entre aromas florales, los cuales sugieren su cualidad de recién nacido, vitalidad, presencia espiritual y pureza («y en el aire pone aroma/ de menta, luna y jazmín!», 2017a: 50; «Aquí está luciendo/ más rosa que blanca. [...]/ Frescor y primor/ lucen para siempre/ como en una rosa/ que fuera celeste», Carratalá 2005: 26); al mismo tiempo que se lo presenta como emisor de tiernas risillas, las cuales simbolizarían el gozo, la armonía, el encanto, la belleza y la gracia («En la garganta del niño/ cantan los ríos del alba», 2017a: 50; «Los hoyuelos ríen/ con risas calladas», Carratalá 2005: 26).

En cuanto a los ángeles, al final del poema de Odio se los presenta como seres partícipes de la celebración que, por lo mismo, se mueven de un lado a otro del marco espacial («arcángeles fatigados/ vienen y van contra el viento», 2017a: 51); mientras que, en «[¿Quién ha entrado en el portal]», los ángeles aparecen interpretando la música celestial en la escena («Una escala de oro y música,/ sostenidos y bemoles/ y ángeles con panderetas/ dorremifasoles», Carratalá 2005: 23).

El segundo poema navideño de Odio, «Huida de San José, el Niño y la Virgen», retoma el pasaje bíblico del escape a Egipto: 
Después de marchar los Magos, el Ángel del Señor se le apareció en sueños a José y le dijo: «Levántate, toma al niño y a su madre y huye a Egipto. Quédate allí hasta que yo te avise, porque Herodes buscará al niño para matarlo».

José se levantó; aquella misma noche tomó al niño y a su madre y partió hacia Egipto, permaneciendo allí hasta la muerte de Herodes. Así se cumplió lo que había anunciado el Señor por boca del profeta: Llamé de Egipto a mi hijo. (Mateo 2: 13-15)

Este mismo pasaje es recreado en "Víspera de la huida a Egipto», la decimocuarta parte de «Navidad», de Alberti, a través del diálogo entre san José y un albardero y un mulero, a quienes les pide, respectivamente, «La albarda mejor de todas» y «La mejor mula de todas» (Carratalá 2005: 10), a fin de prepararse con los mejores medios para sacar de Jerusalén a María y el Niño. En el texto de Odio, el estribillo enfatiza igualmente en el medio ecuestre usado por san José: «Bendita viene la Virgen/ en un caballito blanco» (2017a: 108).

Como parte de la prosopografía de la Virgen, en este caso se le atribuye la característica de ser morena: «Morena tiene la gracia,/ moreno el vuelo del manto» (Odio 2017a: 108). Esta caracterización recuerda a la misma dada a Anunciación de los Reyes, encarnación de la figura de María, en «San Gabriel (Sevilla)», de García Lorca. En este poema, se traslada el escenario típico del pesebre al entorno sevillano y, por consiguiente, se observa una agitanización de los actantes líricos (Carratalá 2005), de modo que el arcángel es presentado como un joven gitano y la Virgen, como una humilde gitana: «Morena de maravilla» (García Lorca 2013: 384).

En definitiva, nótese que los dos poemas navideños de Odio comparten con los citados del 27 no solo el fondo temático; sino también, por un lado, el isosilabismo octosilábico propio de la poesía popular; y, por otro, la estilización propia de la poesía deshumanizada (Ortega y Gasset 1999), al menos en alguna medida, ya que aunque impera la objetivación y la distancia intelectual con respecto a los actantes líricos y el entorno típico del motivo temático, en ocasiones la adjetivación y la función modal de la voz ${ }^{11}$ inscriben juicios valorativos y emotivos.

\section{Poesía social}

Liscano (1975) y Vallbona (1980) señalan que es conocida la filiación de Odio durante su juventud por los partidos de izquierda, aunque luego rompiera con la intelectualidad de esta tendencia. Muñoz y Acuña (en prensa) demuestran cómo esta poeta diversifica los discursos de la intelectualidad costarricense que respalda la causa republicana, en una serie de ensayos y cartas que escribe en relación con la guerra civil española, pero no de manera simultánea a dicho

\footnotetext{
${ }^{11}$ De acuerdo con López-Casanova (1994), este aspecto de la voz lírica se relaciona con las actitudes proposicionales que ella incluya, mediante los verbos modales (deber, creer, saber, querer, soler y poder), en el enunciado y rijan el sentido de este.
} 
acontecimiento bélico ni al triunfo nacionalista. Las investigadoras afirman, en primer lugar, que, pese a simpatizar con las luchas del bloque de izquierda en la Península, Odio evidencia su fragmentación. En segundo lugar, y gracias a la distancia temporal del suceso, la autora cuestiona la manipulación que se verifica desde la narrativa histórica, específicamente en los silencios sobre la intervención rusa y sus vínculos con el bando vencido. Para Muñoz y Acuña, al revisar la complejidad y coherencia interna del tramado argumentativo de Odio se logra observar no solo el abordaje maniqueo de la postura ideológica de dicha autora como «anticomunista», sino también su fijación como «poeta metafísica» por parte de la crítica literaria.

Frente a esta postura expresa en sus ensayos y cartas, Odio inscribe en los dos únicos poemas de corte social-comprometido, «Nube y cielo mayor»y «Pepón de la Campa», una identificación con las causas políticas izquierdistas y una denuncia del fascismo, que llevan a los sujetos líricos a manifestar una clara simpatía con las luchas republicanas durante la guerra civil española (Vallbona 1980, Odio 2018); y, por consiguiente, una empatía con sus héroes y víctimas durante este hecho. Oliva Medina (2011) únicamente menciona estos dos poemas. Del primero dice que es el más largo poema de la serie que poetas costarricenses le dedican a España con motivo de la Guerra Civil, y que en él «se invocan las múltiples facetas del miliciano, aún en fechas tan tardías como 1943» (107). Sobre el segundo no dice nada.

Por una parte, «Nube y cielo mayor» constituye un himno de 119 versos irregulares. Presenta cuatro macrounidades. En la primera (vv. 1-38), se exaltan la figura, orgullo, valentía y resistencia de los milicianos, debido a su sangre derramada, los cadáveres y ante la fuerza popular debilitada; todo en defensa de las proles españolas, contra el dolor vivido de las mujeres y la destrucción de las ciudades por las fuerzas aéreas y bombardeos. En relación con esto último, se evoca el azote de Guernica. En la segunda macrounidad (vv. 39-76), se continúa exaltando al miliciano, pese a los traumas y heridas físicas y culturales que la guerra le ha dejado: aceptar y aprender al nuevo orden del régimen; las condenas, encarcelamientos, castigos y fusilamientos, instituidos como lecciones morales, políticas y sociales; la melancolía y dolor de los derrotados, su inferiorización, la pobreza, las fosas comunes. En la tercera macrounidad (vv. 77-98), se sigue dicha exaltación del miliciano en contraste con el bando sublevado y los agentes políticos, sociales y ultracatólicos que se muestran indiferentes o se placen con humillar, denigrar, reducir, torturar, desaparecer y disolver clandestinamente las fuerzas republicanas y, en consecuencia, mutilar a toda una joven generación. Finalmente, en la cuarta macrounidad (vv. 99-119), al igual que en la dedicatoria («A los milicianos dentro y fuera», Odio 2017a: 15), se hace referencia no solo a los ciudadanos que aún permanecen en la España franquista, sino también a esa 
España peregrina que, ${ }^{12}$ debido a la Guerra Civil, se refugió en América y trajo consigo a este continente sus heridas físicas, psíquicas y culturales. Ante ello, el hablante lírico utiliza el desdoblamiento en primera persona plural, para amplificar la esperanza, el amor, la hermandad y el orden frente a la experiencia traumática de posguerra. Tales valores permitirían que se estrecharan de nuevo los lazos sociales y políticos que llevarían a los españoles republicanos a la unión entre sí y con los americanos, de modo que se fundara una nueva comunidad hispánica desde este lado del Atlántico; una confiada en el porvenir, a cuyos miembros españoles, según el poema de Odio, habría que llamar «conterrados», término de Juan Ramón Jiménez, antes que «transterrados», término de José Gaos (Lago 1997):

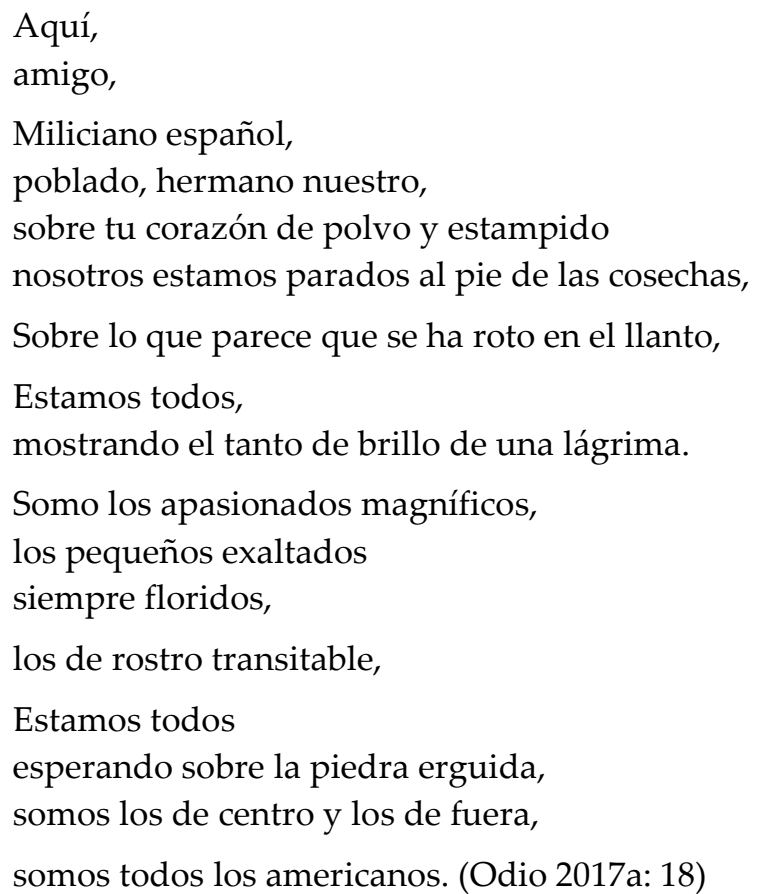

En dicho poema, se pueden escuchar ecos de motivos que no son exclusivos del Grupo del 27, pero que sus integrantes enfatizaron significativamente en múltiples de sus poemas publicados, por ejemplo, en Poetas en la España leal ${ }^{13}$ y Romancero general de la Guerra Española. ${ }^{14}$ Entre tales motivos se encuentran:

${ }^{12}$ Con la frase «España peregrina», José Bergamín tituló en 1940 su revista literaria fundada en México; fue una de las primeras impulsadas por los desterrados en América (Lago 1997). A propósito, recuérdese que parte de esta España peregrina fueron Salinas, Guillén y Ana María Martínez Sagi en Estados Unidos; Cernuda, Emilio Prados, Champourcín Juan José Domenchina, Luisa Carnés, Concha Méndez y Manuel Altolaguirre en México; Alberti en Argentina; y, en este último país, pero en Brasil también, Rosa Chacel.

${ }^{13}$ Libro preparado por los organizadores del Segundo Congreso Internacional de Escritores para la Defensa de la Cultura como regalo a los escritores antifascistas, venidos en julio de 1937 a expresar su solidaridad con la República española (Aznar Soler 2018).

${ }^{14}$ La primera edición fue publicada en 1937, con prólogo de Antonio Rodríguez Moñino. Alberti la reedita, con su propia selección y prólogo en 1944 en Buenos Aires. 
1) La exaltación de la figura del miliciano en «Modesto» ${ }^{15} \mathrm{o}$ «La toma de Caspe», ${ }^{16}$ de Altolaguirre; «Se levantan los muertos»,17 «A la brigada motorizada 'Hierro' $»{ }^{18}$ «A los camaradas del batallón Thaelmann y a Modesto Guilloto, su comandante» ${ }^{19}$ o «Fragmento de carta», ${ }^{20}$ de Prados; «Defensa de Madrid, defensa de Cataluña», ${ }^{21}$ de Alberti; «El miliciano desconocido (Frente de Madrid)»,22 de Aleixandre; o bien «El hombre del momento»,23 de José Moreno Villa. En estos casos, se canta al miliciano en general o inclusive anónimo; pero, de todas formas, ellos evocan —al decir de Alberti - al «camarada muerto violentamente, injustamente, [que] no desparecería del todo si entregaban su nombre a la perdurabilidad de la poesía» (1944: 10). Tal perdurabilidad y exaltación del miliciano también se logra en el poema de Odio: «Salud/ Miliciano Español/ a tu frente miliar/ y a la turbia excelencia de tu sangre» (2017a: 16).

15 «Estoy pensando en ti sin conocerte;/ tu nombre pertenece a ese racimo/ de nombres legendarios que uno teme/ encontrar cada día entre los muertos./ Deja que sueñe, amigo, camarada;/ quiero tener derecho a bendecirte» (Anónimo 2018: 39).

16 «ved el victorioso avance/ de las heroicas Milicias/ que nos llegan de Levante» (Alberti 1944: 195).

17 «Sus altísimas sombras forman ya multitudes;/ como una muda selva de sombra y de gemido/ lentos van, como el peso de las piedras que rinden/ donde aún viven los cuerpos su abandono en la lluvia» (Anónimo 2018: 126).

18 «España: ¡Queda tranquila!/ ¡Mira a tus hijos valientes,/ luchando sobre tu espalda,/ que con sus vidas defienden!/ Tus carreteras, España,/ sobre tu cuerpo se encienden;/ si hoy tronchadas te desangran,/ jaún hay sangre suficiente/ en ellas para inundar/ la injusticia en que te prenden!/ ¡En pie, 'Brigada de Hierro'!» (Alberti 1944: 92-93).

19 «Un puñado de valientes/ dan el sol a la pelea;/ son del corazón de auroras/ y rayos de bayonetas;/ banderas de los combates/ es el batallón de Thaelmann» (Alberti 1944: 97).

20 «Ni ellos conocen mi nombre/ ni yo sé cómo nombrarles./ Sólo el nombre del que muere/ entre nosotros se sabe;/ no por llorar su recuerdo,/ pero sí por imitarle,/ que el que por nosotros muere,/ no muere, sino que nace,/ y no hay hermano que caiga/ que una espiga no levante» (Alberti 1944: 104).

${ }^{21}$ «Fuentes de valor y hombría/ las guardas tú donde siempre [...] Los hombres, como castillos;/ igual que almenas, sus frentes;/ grandes murallas, sus brazos;/ puertas que nadie penetre» (Alberti 1944: 15-16).

22 «No me preguntéis su nombre,/ que no habrá quien lo recuerde./ Cada día se levanta/ con la aurora o el poniente,/ salta, empuña, avanza, arrolla,/ mata, pasa, vuela, vence;/ donde se planta, allí queda;/ como la roca, no cede;/ aplasta como montaña,/ y como la flecha, hiere./ Madrid entero lo adivina;/ Madrid late por sus sienes [...]/ No sé quién fué [sic], quién ha sido:/ ¡toda la ciudad lo tiene! $[\ldots] /$ Un cuerpo, un alma, una vida,/ como un gigante se yerguen/ a las puertas de Madrid/ del miliciano valiente./ ¿Es alto, rubio, delgado?/ ¿Moreno, apretado, fuerte?/ Es como todos. Es todos. [...]/ Se llama Andrés o Francisco,/ se llama Pedro Gutiérrez,/ Luis o Juan, Manuel, Ricardo,/ José, Lorenzo, Vicente.../ Pero, no. Se llama sólo/ Pueblo Invicto para siempre» (Alberti 1944: 55-56).

${ }^{23}$ «Botas fuertes, manta recia,/ fusil, pistola: es el hombre./ Barba hirsuta, barba intonsa,/ saliva e imprecaciones,/ pisar duro, mirar fijo,/ dormir vestido: es el hombre. [...]/ Bajo la lluvia inverniza/ y entre los graves cañones,/ le veo por la ciudad/ devastada, serio y noble,/ como un vástago que busca/ su raíz. Éste es el hombre» (Alberti 1944: 253-254). 
2) Los derramamientos de sangre en «Capital de la gloria», ${ }^{24}$ de Alberti; «Arenga», ${ }^{25}$ de Prados; o "José Colóm», ${ }^{26}$ de Altolaguirre. Dice el sujeto lírico odiano: «Ardía la arteria triste desnudada/ [...] griterío original de días degollados» (Odio 2017a: 15 y 16).

3) Los cadáveres y su pudrición en «La toma de Caspe»; ${ }^{27}$ «Insomnio», ${ }^{28}$ de Alonso; «Elegía española», ${ }^{29}$ de Cernuda; "La guerra», ${ }^{30}$ de Martínez Sagi. Se lamenta el sujeto lírico: «Porque en España/ se cubrían de lujosos cadáveres/ los párpados de las muchachas» (Odio 2017a: 15).

4) El llanto, luto y miseria de las mujeres ante la mutilación y el desangramiento de sus hijos y esposos en «Madrid, Madrid, mi Madrid»,, 1 de Lucía Sánchez Saornil; «Poemas a los niños que mueren en la guerra», de Carmen Conde; o «Digan, digan», 33 de Prados. El sujeto lírico odiano contrasta a la figura del miliciano la realidad de los enlutados, a fin de que encuentren en aquel el consuelo y la fuerza para continuar vivos y luchando: «Porque en España,/ cuando los enlutados/ pacían en tu dulzor enrojecido,/ y comían de tu carne derramada,/ tú eras como un ángel escolar/ en la esquina del mundo» (Odio 2017a: 16).

5) Los bombardeos aéreos en "Capital de la gloria», ${ }^{34}$ «Defensa de Madrid, defensa de Cataluña», ${ }^{35}$ «Madrid, Madrid, mi Madrid»; 36 «Descanso de un

24 «Son pedazos de sangre de tu terrible aurora» (Anónimo 2018: 21).

25 «Málaga tuvo banderas/ que ondearon como llamas/y hoy tiene sólo tristezas/y sangre sobre su espalda./ Mirad, mirad, españoles;/ mirad qué roja está el agua/ que corre en el mar del Sur» (Alberti 1944: 158).

26 «Y ve los ríos de sangre/ regando los cementerios;/ ríos de sangre, ríos de sangre» (Alberti 1944: 189).

27 «Un pueblo de campesinos/ contra una turba salvaje/ de mercenario que quieren/ gobernar sobre cadáveres» (Alberti 1944: 195).

${ }^{28}$ «Madrid es una ciudad de más de un millón de cadáveres (según las últimas estadísticas)» (Lama 1997: 261).

29 «Y veo los bruscos muertos/ Caer sobre la hierba calcinada» (Anónimo 2018: 45).

30 «Una selva hostil de triturados cuerpos/ cierra el horizonte. [...]/ Los buitres devoran/ el corazón podrido de los hombres» (Martínez Sagi 2019: 63).

31 «—iMadre, madre, me han matado/ al hijo de mis entrañas!» (Wineruda s.f.: §18).

32 «iNiños, niños da la guerra al polvo seco y áspero, mordido de lirios y de mariposas! ¡Niños tiernos del estremecimiento de sus padres, bajo la metralla, trizados como mazorcas que desgranara mano de hierro!» (Conde 1938: s.p.).

${ }_{33}$ «Yo he visto morir las madres/ que aún ser madres no pudieron,/ y dejar su vientre frío/ con un leve movimiento,/ bajo la sangre cuajada/ que apagó el soplo más negro» (Alberti 1944: 140).

34 «Un cielo temeroso de explosiones y llamas./ Capital ya madura para los bombardeos» (Anónimo 2018: 19).

35 «Rondan por tu cielo halcones/ que precipitarse quieren/ sobre tus rojos tejados,/ tus calles, tu brava gente» (Alberti 1944: 15).

36 «Debajo de las estrellas/ los negros aviones cantan,/ serpientes de traición silban/ que hasta a al muerte acobardan» (Wineruda s.f.: §21). 
miliciano» ${ }^{37} \mathrm{o}$ «Madrid y sus enemigos», ${ }^{38}$ de Moreno Villa; «Alarma», ${ }^{39} \mathrm{de}$ Chacel; «Soledad de Málaga», ${ }^{40}$ de Prados. El sujeto lírico se refiere al cielo encendido por los aviones bombarderos con la metáfora: «tu cielo veloz acuchillado» (Odio 2017a: 15).

6) La destrucción y ruinas de ciudades en "Capital de la gloria», ${ }^{41}$ «Elegía española»; ${ }^{42}$ «Canto de vida y esperanza», ${ }^{43}$ de Altolaguirre; «Arenga» ${ }^{44} \mathrm{O}$ «Meditación en la noche», ${ }^{45}$ de Prados. Describe generalizadoramente el sujeto lírico: «encubierto de escombros doloridos» (Odio 2017a: 15).

7) El nuevo régimen que divide políticamente al país en «A los camaradas del batallón Thaelmann y a Modesto Guilloto, su comandante ${ }^{46} \mathrm{O}$ «Es la tierra de nadie», ${ }^{47}$ de Altolaguirre. Le indica el sujeto lírico al miliciano español: «tú estabas con el rostro dividido» (Odio 2017a: 17).

8) La humillación y fusilamientos de los milicianos y republicanos en «Digan, digan» ${ }^{48} \mathrm{o}$ «El fusilado», ${ }^{49}$ de Aleixandre. El sujeto lírico eleva, en nombre de todos los españoles torturados que defendían la República, su denuncia: «Porque cuando los militares de medio rostro/ mutilaban la era embarazada» (Odio 2017a: 17).

9) La inmoralidad, corrupción, despotismo, traición, tiranía y oportunismo de los fratricidas del bando sublevado en «Defensa de Madrid, defensa de

\footnotetext{
37 «Mientras los pájaros enemigos/ duchan con bombas la ciudad» (Anónimo 2018: 114).

38 «iSomos todas esas casas/ que el bombardeo aniquila!» (Alberti 1944: 54).

39 «Una batalla de arcángeles/ se libra bajo la luna. / Sus alas, rojas o negras,/ veloces el cielo surcan/ con maléficos destellos,/ con claras estelas puras. Sus fragorosos alientos/ con ira pasando zumban./ Lanzas de fuego se arrojan,/ que encendidas se entrecruzan; meteoros de la tierra/ brotan, siguiendo su ruta» (Alberti 1944: 36).

40 «QQué agudas alas de muerte/ por las nubes acechaban!» (Alberti 1944: 156).

${ }^{41}$ «Avenidas de escombros y barrios en ruinas» (Anónimo 2018: 19).

42 «Que por encima de estos y esos muertos/Y encima de estos y esos vivos que combaten/ Algo advierte que tú sufres con todos» (Anónimo 2018: 46).

43 «La última muerte de esta guerra/ se desprendió de su ruina» (Anónimo 2018: 32).

${ }^{44}$ «Que ve sus hermanos muertos/y sus tierras devastadas,/ que ve rota su familia/ y vió [sic] en ruinas su casa» (Alberti 1944: 158).

45 «Los brazos de sus árboles, quemados/ se levantan al cielo ignominiosos;/ tronchadas sus acequias se desangran/ sobre su pecho roto y sus ruinas./ En cenizas el viento se dilata/ ahogando en el terror su gran hoguera:/ Guerra, tu sombra con su yerto frío/ poblando está la tierra en que agonizas» (Anónimo 2018: 123).

${ }^{46}$ «i $\mathrm{Al}$ ataque; hay que cercarla;/ que sea nuestra roja estrella/ la que libere Madrid,/ y clavada como espuela/ en los flancos del fascismo,/ lo haga huir de nuestras tierras!» (Alberti 1944: 100).

47 «No se ve ni se siente, no se sueña/ la fatídica franja divisoria./ Pero allí está, como un reptil, inmóvil» (Lama 1997: 395).

${ }_{48}$ «Malos tiros traicioneros. [...]/ -Menos palabras, muchacho./ ¡Arriba los brazos!... ¡Fuego!/ ¡Ay, mala tarde de muerte;/ tarde corazón hueco!» (Alberti 1944: 138).

49 «Apuntan nueve fusiles/ a aquel noble y limpio pecho,/ espejo de milicianos/y de valientes espejo,/ y del desdén de su boca/ un salivazo soberbio/ va a aplastarse entre los ojos/ del jefe, vil fusilero» (Alberti 1944: 83-84).
} 
Cataluña», ${ }^{0}$ "A los camaradas del batallón Thaelmann y a Modesto Guilloto, su comandante», 51 «Digan, digan», 52 «La toma de Caspe»,53 «Elegía española», ${ }^{54}$ «Un español habla a su tierra» ${ }^{55}$ o «Ser de Sansueña», ${ }^{56}$ de Cernuda. El sujeto lírico odiano señala la institucionalización y comodidad de los traidores y corruptos de la patria, sobre la muerte de los españoles republicanos y milicianos:

porque aun/ entre los relojes de los bufetes/y de los tocadores,/ los arzobispos y los medios rostros de los traidores,/ se masturban la mente con un paraguas,/ y en tu España,/ en la mía,/ en la de todos,/ aún arde tu cuerpo como un clavel de asalto. (Odio 2017a: 18)

10) El destrozo de las jóvenes generaciones en tanto víctimas de la guerra en «Alarma», 57 «La guerra»,58 «Se levantan los muertos», 59 "A los camaradas del batallón Thaelmann y a Modesto Guilloto, su comandante» ${ }^{60} \mathrm{O}$ «Pájaros de victoria», ${ }^{61}$ de Prados; «Vosotros no caísteis», ${ }^{62}$ de Alberti; o «Elegía a la luna de España», ${ }^{63}$ de Cernuda. Canta patéticamente el sujeto lírico odiano: «Salud hasta en tu niño fusilado/ que deslinda su ombligo entre tu frente» (Odio 2017a: 17).

50 «Qué festín de generales/ borrachos, ante una mesa/ donde por blancos manteles/ se usaran ropas sangrientas!» (Alberti 1944: 17).

51 «A las armas, compañeros,/ que los traidores intentan/ vender nuestros blandos ríos,/ nuestras fértiles praderas,/ la llama de nuestros toros,/ la piel de nuestras dehesas,/ al aire de nuestros pájaros,/ el oro de nuestras piedras,/ la flor de nuestras hermanas,/ el sudor de nuestras venas!» (Alberti 1944: 98).

52 «Digan, digan ellos, digan;/ que con engaños y enredos,/ con crímenes y traiciones/ no se ganó en ningún tiempo» (Alberti 1944: 141).

53 «El infame,/ con el cuerpo de una niña/ se atrinchera. ¡Miserable!» (Alberti 1944: 196).

54 «Mira cuántos traidores,/ Mira cuántos cobardes [...]/Y su odio, su crueldad, su lucha,/ Ante ti vanos son como sus vidas» (Anónimo 2018: 45-46).

55 «Ellos, los vencedores/ Caínes sempiternos,/ De todo me arrancaron./ Me dejan el destierro» (Lama 1997: 325).

56 «La nobleza plebeya, el populacho noble,/ La pueblan; dando terratenientes y toreros,/ Curas y caballistas, vagos y visionarios,/ Guapos y guerrilleros. Tú compatriota,/ Bien que ello te repugne, de su fauna» (Lama 1997: 334).

57 «Pesados cuerpos de niños,/ arrancados de las cunas,/ estremecidos, se acogen/ al seno que los refugia» (Alberti 1944: 35).

58 «Ya se están enfriando los ojos de los niños./ Ya la muerte amordaza la risa de los jóvenes» (Martínez Sagi 2019: 63).

59 «Con los tristes harapos de los niños profundos,/ los que al combate entraron desnudo todo el pecho/ y ahora los cruza el aire como a viejos castillos» (Anónimo 2018: 127).

60 «Más alta se hará la hoguera/ que nuestros huesos calcina/ y nuestra juventud quema!» (Alberti 1944: 98-99).

61 «Mirad, mirad que segura/ nuestra juventud avanza/ como una flor de banderas/ sobre las altas montañas» (Alberti 1944: 87).

62 «Siembra de cuerpos jóvenes, tan necesariamente/ descuajados del triste terrón que los pariera» (Anónimo 2018: 23).

63 «Sobre el antiguo campo de batalla, Fertilizado por tanto cuerpo joven» (Anónimo 2018: 4748). 
11) Los sentimientos de sometimiento, temor, humillación, dolor y melancolía de los vencidos en «Ciudad eterna (Madrid 1937)», ${ }^{64}$ «Digan, digan», ${ }^{65}$ «Romance del desterrado» ${ }^{66} \mathrm{y}$ «Soledad de Málaga», ${ }^{67}$ de Prados. Se duele el sujeto lírico al visualizar:

Salud a tu lacónica silueta/ melancólico el gesto entre las rocas,/ y la mirada envuelta en una lágrima,// Salud/ hasta tu corazón más íntimo,/ y en tu sudor más íntimo,/ y hasta en el dorso/ más olvidado de tu hueso,/ desordenado y alto. (Odio 2017a: 16-17)

Por otra parte, en el poema «Pepón de la Campa», se enuncia la defensa sangrienta de todos los flancos de España a cargo del bando republicano, después del fracaso parcial del golpe de Estado en julio de 1936. Por esto, se exaltan el espíritu guerrillero, la respuesta, unidad y fortaleza de los milicianos. Todos estos valores son encarnados en la figura ejemplar del dinamitero Pepón de la Campa. Sobre él dan información el epígrafe del poema («A Pepón de la Campa,/ por su metro noventa/ de estatura y sus/ dos mil metros de España», Odio 2017a: 19) y una nota de Odio al pie («Pepón de la Campa es asturiano. Guerrillero asturiano. Es decir, de los que no se conformaron a lo último, y desembocaron en las montañas para proseguir la lucha que aún hoy, no ha cesado. Valgan estos Pepones y estos hombres para la España que aguardamos», 20). Bello (2011) recopila también datos sobre Pepón de la Campa: «un héroe del bando republicano [...], que vino conteniendo a la fuerza de los requetés navarros desde el Mazucu hasta Les Pieces» ( $\S 9$ y 16). Con estas notas no solo se evoca la resistencia y valentía de Pepón de la Campa y el frente asturiano ante los sublevados nacionalistas; sino también la revolución asturiana, intento fracasado de golpe de estado, que en octubre de 1934 se alzó contra el gobierno de derechas, el cual a cargo de Alejandro Lerroux tomó el mando del país durante el Bienio conservador (1933-1936).

Por lo anterior, el poema se orienta a construir una ejemplar etopeya de dicho dinamitero: insumiso, valiente, vigilante, fuerte, comprometido, alentado con el grito de guerra, rudo, resistente, justo, bueno; en fin, defensor de la patria y la vida, aunque también agotado, errático, angustiado, herido y masacrado. A propósito, el motivo del grito de guerra que alienta a los milicianos se presenta igualmente en «Arenga», de Prados. ${ }^{68}$

\footnotetext{
${ }_{64}$ «Menos dura la piedra/ a sumisión se rinde./ Menos dura la piedra/ también sin dolor nace» (Anónimo 2018: 119).

65 «Dicen que nuestra justicia/ es terror y mal deseo;/ que ningún calor humano/ arde en nuestro sentimiento» (Alberti 1944: 138).

${ }_{66}$ «No tengo casa ni amigo,/ no tengo un lecho caliente,/ ni pan que calme mis hambres,/ ni palabra que me aliente./ ¡Ay, cuerpos desheredados!» (Alberti 1944: 148).

67 «Tristeza que no se calma,/ pues si el fascismo mordiera/ sobre las tierras de España,/ ¿qué olvido habrá para el llanto/ si es la libertad esclava?» (Alberti 1944: 157).

68 «iUnión, unión, proletarios,/ hijos valientes de España! [...] ¡Afuera, afuera invasores,/ que nuestra tierra es muy cara/ y nuestra sangre muy roja/ para que se sienta esclava! [...]
} 
Pese a la concesión del párrafo anterior, la insumisión de Pepón es remarcada significativamente a lo largo del texto mediante: 1) el paralelismo de «Dinamitero insumiso», en los versos 2, 7, 24 y 39; 2) la reduplicación del nombre «Campa», la cual sugiere el desplazamiento de este dinamitero ejemplar a través del campo, en medio de la campaña u operación militar; 3) la onomatopeya creada por los fonemas oclusivos en el nombre «Pepón de la Campa Campa» (vv. 1, 6, 20 y 38), la cual refuerza aquel paralelismo y connota los estruendos de las explosiones de dinamita que aquel detonaría en medio de la campaña; 4) la ruptura del isosilabismo octosilábico cuando se acentúan, justamente, a través de la disonancia creada por el tetrasílabo, pentasílabo, heptasílabos, eneasílabos y endecasílabos, el desgaste, los peligros y las lesiones que en la adversidad del combate Pepón enfrenta. Resulta, por consiguiente, también significativo que, cuando se enuncia la resistencia y convicción del dinamitero en oposición a esta adversidad, se retome aquel isosilabismo a fin de señalar la entereza del miliciano ante la guerra.

Obsérvese que el poema utiliza el octosílabo propio de los romances, aunque no llega a ser uno, pues se rompe el isosilabismo en los versos 25-34 y falta la asonancia en versos pares. Odio, más bien, juega libremente con la rima e incluso compone la segunda estrofa como una soledad. ${ }^{69}$ Pese a las diferencias e innovaciones con respecto a la forma poemática del romance, se podría suponer cierto impulso romancero en el texto de Odio, ya que usa mayoritariamente el octosílabo, medida tradicional popular, para cantar un tema afín a la Guerra Civil. Recuérdese que el romance fue retomado primeramente por Prados durante la guerra para expresar tanto la indignación, críticas y denuncias contra los sublevados, sus ataques, el fascismo, daños sociales, psicológicos, humanos del conflicto bélico; así como para alentar, honrar, distinguir el esfuerzo, valentía, entrega, muerte o ejemplaridad de algún batallón, aviador, militar, soldado o miembro de la milicia, como Pepón de la Campa. Por lo anterior, el romance resurgió como el soporte predilecto para los «poemas de la guerra y la revolución» (Aznar Soler 2018: 16).

Con respecto al heroísmo, en los versos

Pepón de la Campa Campa/ dinamitero insumiso,// Pepón te llaman a gritos,/ turbiones del Guadarrama/ y alertas de los olivos [...]// Te llevan veinte mil hombres/ en sus solapas gastadas,/ y en sus sudores más íntimos (2017a: 19)

resuenan los versos de Alberti en «Lejos de la guerra»:

¡Valencianos! ¡Españoles! [...] ¡Viva nuestra independencia!/ ¡Viva libre nuestra España!» (Alberti 1944: 159).

${ }^{69}$ Paldao y Vallbona (Odio 2018) ofrecen otra versión de este poema con una división estrófica distinta, de modo que los versos 19-21 conformarían también una soledad. 
Yo diré tu heroísmo de nuevo y simplemente,/ lejos de ti, ciudad, con la voz merecida/ del hombre que por norma ya tiene diariamente/ anochecer sin casa o amanecer sin vida (Anónimo 2018: 25)

o bien los de Altolaguirre en «Madrid, 1937»: «ante este inmenso campo de heroísmo» (Anónimo 2018: 37).

En algunos poemas del 27, resulta frecuente la exaltación de la figura del miliciano encarnada en algún personaje histórico o ficcional, que pasaría a representar, como Pepón de la Campa, el heroísmo republicano. Tanto Alberti en «A Hans Beimler, defensor de Madrid», ${ }^{70}$ como Prados en «Romance dedicado al camarada Hans Beimler, muerto heroicamente durante el sitio de Madrid»,71 cantan la valentía y solidaridad que tuvo con el pueblo español el diputado del Parlamento alemán y miembro del Partido Comunista de Alemania, Hans Beimler. Este se unió a las Brigadas Internacionales y falleció en el frente de Madrid. Aleixandre, en «El fusilado», ${ }^{72}$ compone el retrato del joven José Lorente Granero. Prados exalta al comandante del batallón Thaelmann, ejemplo de firmeza y confianza en los milicianos que defienden Madrid contra el fascismo. ${ }^{73}$ Altolaguirre, por un lado, elogia «A Saturnino Ruiz, obrero impresor» — suyo y de García Lorca-, quien cayó en la batalla de Somosierra; ${ }^{74}$ el sujeto lírico interpela al militar Francisco Galán, para que atestigüe la valentía y entrega de Ruiz hasta el final. Por otro, recuerda a «José Colóm», capitán de las Fuerzas Aéreas de la República Española, quien sacrificó su vida para impedir el avance del bando sublevado, y cuya valentía ejemplar sigue viva entre los milicianos. ${ }^{75}$

\footnotetext{
70 «'¡Frente Rojo!', y cayó en tierra/ castellana, de leales,/ quien vino desde muy lejos/ a sembrar aquí su sangre./ ‘Frente Rojo!' Que lo escuche/ la Alemania de las cárceles/ y verdugos que levantan/ las secas hachas, que caen/ sobre los cuellos que nunca/ jamás quisieron doblarse» (Alberti 1944: 45).

${ }_{11}$ «Dicen que vas muerto, hermano;/ pero tu vida no acaba/ porque se sequen tus venas/y se hiele tu garganta./ Si están tus venas vacías,/ nuestra tierra está empapada,/ y aún caliente con la sangre/ que de tu corazón falta [...] Si están tus brazos tranquilos,/ aún se mueven tus hazañas/ por los campos de Castilla/ entre el rumor de las armas» (Alberti 1944: 47).

72 «Veinte años justos tenía/ José Lorente Granero [...]/ Miradlo erguido en el monte,/ hermoso, fuerte y sereno,/ héroe entre sus camaradas,/ entre las balas ileso. [...]/ ¡Ay, voz que cantas la vida/ de este muchacho del pueblo,/ honor de la gesta heroica,/ José Lorente Granero [...]/ José no murió. ¡Miradlo!/ ¡Resucitado; no ha muerto!/ ¡Que no murió; como no/ morirá jamás el pueblo» (Alberti 1944: 82-85).

73 «Modesto, mi comandante,/ buen maestro de firmezas,/ conozco tus milicianos/y la fe que los alienta;/ ahora, en tu nueva brigada/ su levadura fermenta./ ¿Qué rojo pan de victorias/ tendrá el batallón Thaelmann! » (Alberti 1944: 100).

${ }^{74}$ «Si él hace la causa justa,/ tú haces la victoria cierta./ Saturnino Ruiz, valiente/ héroe de la clase obrera,/ ¡cuando se muere luchando/ no se acaba la pelea;/ el héroe que muere de pie/ sobrevive a la contienda!» (Alberti 1944: 88-89).

75 «Capitán José Colóm,/ yo sé que estás en tu puesto,/ que quien muere como tú/ no abandona nuestro ejercito./ Tu nombre glorioso está/ firme en las líneas de fuego,/ y hazañas como la tuya/ son el mejor parapeto/ para impedir el avance/ del desalmado armamento./ Tú te quedaste sin armas,/ pero aún te quedaba el cuerpo:/ te quedaba tu aeroplano,/ y no dudaste un momento/ en derribar con tu muerte/ al invasor traicionero» (Alberti 1944: 190).
} 
El poema de Odio enaltece la condición bélica de Pepón de la Campa como dinamitero miliciano. Esta figura se puede encontrar igualmente, en el nivel intratextual, en «Nube y cielo mayor» («Dinamitero que ardes/ con tu boca en armas/ y tu fragor al cinto», 2017a: 17); o bien, en el nivel intertextual, en poemas como «La torre de El Carpio», ${ }^{76}$ de Altolaguirre; y también —más allá de la polémica historiográfica de si Miguel Hernández es epígono del 27 o miembro de pleno derecho de dicho Grupo ${ }^{77}$ (Díaz Pardo 2018) - en «Rosario, dinamitera», poema hernandiano donde la histórica miliciana Rosario Sánchez Mora, conocida como la Dinamitera, encarna la valentía y fiereza del frente republicano, tanto como Pepón de la Campa. Además, tanto Rosario como Pepón desatan su fuerza bélica en Guadarrama. Sobre la primera, aclara Hernández en el número 39 (23 de enero de 1937) de la revista Ayuda: «Rosario tiene un temperamento fogoso que ha desahogado en el Guadarrama haciendo bombas y arrojándolas al enemigo» (2000: 137). Sobre el segundo, canta el hablante lírico odiano: «Pepón te llaman a gritos/ turbiones de Guadarrama/ y alertas de los olivos» (Odio 2017a: 32).

La insumisión de Pepón está marcada mediante el símbolo de la «frente» («Dinamitero abrupto/ de los propios andamios de tu frente», Odio 2017a: 20), la cual, gracias a la dilogía, evoca tanto la altura, valentía, lucidez, astucia y orgullo del republicano; así como al frente mismo de milicianos. Esta dilogía de «frente» también se observan en «Capital de la gloria», ${ }^{78}$ «Fragmento de carta»; ${ }^{79}$ «Madrid, $1937 »,{ }^{80}$ de Altolaguirre; y en «Frente», ${ }^{81}$ de Moreno Villa.

Una última relación intertextual se puede establecer entre la imagen odiana «los altos olivares» y la reminiscencia que en ella se escucha de los versos: «En lo alto de aquel monte/ hay un arbolito verde.// Pastor que vas,/ pastor que vienes.// Olivares soñolientos/ bajan al llano caliente» (2013: 133), de la primera de las "Cuatro baladas amarillas», en Primeras canciones (1926), de García Lorca. Obsérvese en estos versos la relación no inmediata del adjetivo «alto» y «olivares», pero que el dinamismo de la imagen une desde lejos y, por eso,

\footnotetext{
76 «De estos puntos se destacan/ ocho valientes mineros/ que van a ofrendar sus vidas,/ que van a morir venciendo./ Cargados con dinamita,/ en un camión descubierto/ avanzan hacia la muerte/ por las calles en silencio./ [...] jinmaculado heroísmo/ el de los dinamiteros!» (Alberti 1944: 168). 77 En el ensayo «En defensa del castellano» Odio (2017b) deja constancia de que uno de los poetas leídos por ella y al que considera ejemplar dentro de la nueva poesía contemporánea, porque ejecuta la «imaginación idiomática» (254), esto es, una musicalidad que solo puede ser producto del trabajo sintáctico y fonético de la poesía, a fin de romper el estado natural — pragmático y conceptual— del lenguaje, es justamente Miguel Hernández.

78 «La frente de tu frente se alza tiroteada» (Anónimo 2018: 20).

79 «Tengo un hermano en el frente/ que tú no conoces, madre;/ que el hermano que ahora tengo/ no lleva tu misma sangre./ Un hermano en cada frente/ me atan más que tus dogales» (Alberti 1944: 103).

80 «Mi frente con el frente son sinónimos [...]/ que el frente paralelo de mi frente/ desdeña mi dolor y me acompaña» (Anónimo 2018: 37).

81 «Esto es el frente, duro y seco./ Es la bala y el cuerpo humano,/ es la tierra y el pájaro avieso,/ es la cabeza y es la mano,/ y es el corazón contra el hierro» (Anónimo 2018: 115).
} 
permitiría comprender que aquel «arbolito verde» puede ser un olivo, pues desde aquella cima bajan los «olivares» hasta el «llano». Se trataría, entonces, de una marca que ejemplifica cómo los poetas vanguardistas se prestan consciente o no conscientemente imágenes entre sí, nunca a modo de plagio, sino como señas de identidad, dado que, mediante la convivencia, sutiles complicidades de cenáculo o lecturas, van seleccionando a esos otros autores y autoras afines a un proyecto estético común, como sería el caso de Odio con los del 27 con miras a trazar y defender individual y conjuntamente una estética del lenguaje, pura o impura, según vayan desarrollándose sus poéticas.

En fin, el sujeto lírico odiano exalta la ejemplaridad, valentía y heroísmo de Pepón de la Campa y emplea su figura para representar y alentar simbólica y sinecdótica a todos los combatientes a favor de la Segunda República española. Pepón de la Campa no solo es perfilado moralmente como un héroe que alienta a otros hombres, sino que también representa el ideal de lucha para las nuevas generaciones («Te llevan las niñas fértiles/ en sus cinturas ensoñadas,/ y en sus vientres españoles», Odio 2018: 19). Con dicho actante lírico, se personifica al bando republicano, a fin de cantarlo no solo poética y políticamente, sino también humanitaria y solidariamente, al igual que los del 27 y muchos otros poetas más, españoles o latinoamericanos, como Neruda en España en el corazón (1937) o Vallejo en España, aparta de mí este cáliz (1939).

\section{CONCLUSIONES}

Con este análisis, finalmente se completa el estudio iniciado por Campos (en prensa), dirigido a establecer con la claridad y precisión posibles los legados vanguardistas del Grupo del 27 en la poesía y ensayística de Eunice Odio. En esta ocasión, se han podido comprobar los legados correspondientes al neopopularismo y la poesía social en poemas odianos.

En cuanto al neopopularismo, por un lado, el poema «Zafra» recupera de la tradición cubana y latinoamericana la figura del negro, con el fin de denunciar la marginalidad, injusticias sociales y laborales, llanto, dolor y tragedia que padece, tanto como el gitano, rescatado en el caso del 27 a través de la recuperación vanguardista del cante jondo andaluz. Por otro lado, los poemas «Navidad»y «Huida de San José, el Niño y la Virgen» guardan similitudes retóricas y formales con algunos de los poemas navideños del 27; o bien semejanzas con respecto a la reelaboración de pasaje o personajes bíblicos, manteniendo algunos matices propios de la estilización deshumanizada (Ortega y Gasset 1999), sobre todo con respecto a la composición de metáforas, topografías y prosopografías, aunque también hay que señalar la presencia de juicios valorativos o emotivos que la adjetivación, las mismas prosopografías, la función modal de la voz y las figuras patéticas - preguntas retóricas u optaciones por deseo vehemente (Fernández 1979)_ inscriben. 
De acuerdo con lo anterior, en el neopopularismo odiano, al igual que en el del 27, se observa la alternancia o superposición de rasgos propios de la poesía pura y la impura. Mientras que se comprueba cierta continuidad de los legados de la estilización deshumanizada y el gongorismo en la poesía de Odio (Campos, en prensa), también es verdad que aparecen significativamente rasgos de la impureza, especialmente por la inscripción de las emociones, propias de la realidad natural que tanto pedía suspender y apartar el nuevo arte (Ortega y Gasset 1999).

En esta dirección hacia lo impuro, como la del 27, la poesía neopopularista de Odio evidencia esa corriente viva que, desde el Romanticismo, intenta conectar la lírica con los ideales de perfección estética de la época por su simplicidad, estilización y capacidad de sugerencia. Por eso, se rescata con pasión lo folklórico y popular. En las poesías del 27 y Odio se retoman las tradiciones española y latinoamericana, respectivamente, y se las trabaja estéticamente, considerando la intencionalidad y el deseo de las vanguardias puras de cantar la forma y entendiendo, a la vez, como dice Salinas, que «la tradición es la forma más plena de libertad que le cabe a un escritor» (1983: 369). De ahí que para ambas partes — el Grupo del 27 y Odio_ la tradición no sea algo inmutable ni cerrado; más bien, es necesario que ella le abra paso a la novedad, a la actualización en el presente, para su proyección hacia el futuro. En este sentido, se presenta, por ejemplo, en «Zafra», un paso hacia la innovación temática del negro cubano, proyectándolo hacia las nuevas realidades nacionales y continentales, donde no existan las manifestaciones de exclusión, marginalidad, esclavitud, explotación y violencia de este grupo cultural caribeño y latinoamericano, en términos análogos a los empleados por García Lorca para defender a los gitanos, en cuanto que grupo cultural ancestral de los españoles.

Con lo anterior, se advierte, pues, en la poesía de Odio, el ejercicio de la otra vanguardia: una que, poco a poco, se aleja del vanguardismo formalista, autónomo, inmanente y puro, a fin de rehumanizarse y comprometerse con la vida, su tiempo, la historia, sus camaradas y amigos. Cruzando estas lindes, la poesía odiana se enfoca en la coyuntura de la guerra civil española, la cual le permitió —igual que a los poetas del 27- defender la Segunda República, solidarizarse con esta lucha política, exaltar a los milicianos como figuras heroicas del conflicto, identificarse con las víctimas, denunciar al bando sublevado y la destrucción que este provocó en el país. Esta solidaridad y empatía marcará en parte el americanismo que luego tendrá lugar en varios textos de autores del 27, escritos posteriormente a la década de los 50, pero que ya Odio desde 1946 deja anunciado al final de «Pepón de la Campa». En fin, la práctica de la vanguardia rehumanizada por parte de Odio, así como por algunos poetas del 27, está significativamente determinada por la guerra civil española. Sin duda alguna, su abandono de la poesía pura y su apuesta por el compromiso social son claros y análogos. 
Así las cosas, la poesía de Odio desarrolla, como la del 27, la vanguardia en sus dos vertientes: una primera relativa a la pureza, otra segunda relativa a la impureza. Contrario a lo que se piensa usualmente, la vanguardia no solo tiene que ver con la estética deshumanizada; vanguardia también es aquella de la rehumanización y revolución por las causas sociales y civiles (García 2016). No se olvide que el término «vanguardia» procede del léxico militar; por tanto, ha de comprender también la dialéctica del arte con el compromiso y el realismo sociales.

Como en el 27, la poesía de Odio, inclinada ora a la deshumanización, ora a la rehumanización, se posiciona políticamente, porque —desmintiendo otras falsas creencias - la deshumanización del arte y la poesía pura apuestan políticamente por una postura de renovación cultural. En el caso del 27, según se deduce del ensayo breve «La vuelta al orden» de Diego (1927), el regreso al orden y la pureza responden a un mismo vector: un compromiso de renovación cultural y política promovido por Revista de Occidente y su círculo. La vuelta al orden encerraba un programa ideológico y no solo estético, una ideología artística en correlación con las ideologías políticas o filosóficas de la burguesía para edificar la España del momento. Así, los poetas puros del 27, por tanto, no eran apolíticos. Su vanguardia deshumanizada, pura y autorreferencial no era ajena a la política: justamente planteaba la ausencia interesada de la política. La poesía pura no desplazaba ni ocultaba la dimensión ideológica, más bien la tematizaba y producía textualmente (García 2016): (re)producía la ideología de la forma, una noción básica que se halla estrechamente ligada con la constitución fenomenológica de la realidad desarrollada por Ortega y Gasset (1999).

En el caso de Odio, el ejercicio de la poesía pura también implica ausencias —al menos momentáneas, de escapadas, porque ella atendió en varios ensayos y cartas críticas y denuncias políticas y sociales - de las realidades convulsas que durante los 40 y 50 se vivieron en el nivel centroamericano, tanto en Costa Rica - la guerra civil del 48-, como en Nicaragua, El Salvador o Guatemala, países por donde viajó la poeta entre 1946 y 1952. El ejercicio de la poesía pura y el gongorismo, así como el diálogo con el Creacionismo y la fenomenología, le permitieron a Odio reflexionar y componer una práctica poética y ensayística de una profundidad arquetipal, simbólica, trascendentalista, ontológica y estética, sin precedentes en el nivel nacional y —al decir de Liscano (1975) — en el nivel latinoamericano. Su interés radical era volver a los orígenes primordiales del lenguaje, indagar en la naturaleza de este, reflexionar sobre la creación poética y el poder transmutativo de la palabra. En este sentido, su propuesta puede ser interpretada como afín a los términos en que Bachelard (2017) se refiere a la ensoñación poética, especialmente, referida a la poética del aire. $O$ también afín a los términos de Ortega y Gasset (1999) sobre la propuesta de la deshumanización, con miras a alcanzar las sustancias artísticas y pro-mover, a través del pensamiento, las irrealidades, por medio de las cuales trascendían el lenguaje, el texto y el lector de manera siempre intelectual. Obsérvese que, en 
ambas posibilidades de lectura, se trata de un norte fenomenológico, porque el objetivo de la producción literaria de Odio ha de ser, como para los poetas del 27, el afán de alcanzar la originalidad y perfeccionamiento poéticos.

En suma, se da por terminada esta labor que ha pretendido demostrar, una vez más, a la luz de la producción literaria de Odio y la del Grupo del 27, que los vanguardistas españoles como los latinoamericanos solo llegaron a ser lo que fueron gracias al diálogo que hubo entre ellos en su afán por concebir proyectos poéticos de ruptura.

Ojalá este trabajo sirva como una referencia para que, como se dijo en la primera parte de este recorrido, futuros investigadores que deseen continuar trazando puntos de encuentro entre Odio y el Grupo del 27 acaso respondan interrogantes como: ¿se presentan los legados de la pureza, el gongorismo, el neopopularismo o la estética comprometida del 27 en El tránsito de fuego (1957), otros poemas o ensayos, e incluso cartas, no seleccionados para el corpus acá estudiado o analizado por Campos (en prensa)? De ser afirmativo, ¿de qué manera se presentan?, ¿se mantienen semejanzas o diferencias con respecto a las relaciones intertextuales señaladas aquí o en el trabajo anterior?, ¿se da algún salto cualitativo o no con respecto a estas estéticas en esos otros textos?... No se duda que estas y otras interrogantes puedan surgir con mira a seguir estableciendo relaciones entre las producciones literarias de Odio y el 27; pero, por el momento, termínese el examen aquí.

\section{BIBLIOGRAFÍA}

AlberTI, R. (1944), Romancero general de la Guerra Española, Buenos Aires, Patronato Hispano Argentino de Cultura.

ANÓNIMO (2018), Poetas en la España leal, Sevilla, Renacimiento.

AZNAR SOleR, M., (2018), «Poesía, guerra y revolución», en Poetas en la España leal, anónimo, Sevilla, Renacimiento, 7-22.

BACHELARD, G. (2017), El aire y los sueños. Ensayo sobre la imaginación del movimiento, México, Fondo de Cultura Económica.

BAEZA FlORES, A. (1953), «Eunice Odio: sueño y raíz, misterio y poesía», en Zona en territorio del alba, Odio, E., Mendoza, Argentina, Brigadas Líricas, s.pp.

BAEZA Flores, A. (1978), Evolución de la poesía costarricense, San José, Editorial Costa Rica. BELlo, X. (2011), «Una memoria que se enciende» [en línea]. Gijón, El Comercio, 7 julio 2011. Disponible en: <https:/www.elcomercio.es/v/20110717/gente/memoriaenciende-20110717.html>.

BuRdiel DE LAS HERAS, M. C. (1987), «La poesía bíblica y Eunice Odio», Foro literario, 10 (17), 42-50.

CAMPOS, R. (en prensa), «Algunos puntos de encuentro: pureza y gongorismo del Grupo del 27 en la poesía y ensayística de Eunice Odio», en Centenario de fuego: nuevas aproximaciones a la producción literaria de Eunice Odio conmemoración de su natalicio, Campos, R. y Víquez, A. (eds.), San José, Editorial de la Universidad de Costa Rica. 
CARRATAlÁ, F. (2005), «Los poetas de la Generación del 27 cantan a la navidad» [en línea]. Studylib.es. Disponible en: <https://studylib.es/doc/8742461/los-poetas-dela-generaci\%C3\%B3n-del-27-cantan-la-navidad>.

Cervera, V. (2001), «Vocación de espesura Eunice Odio bajo Sombra del paraíso», en La palabra innumerable: Eunice Odio ante la crítica, Chen Sham, J. y Vallbona, R. de (eds.), San José, Editorial Universidad de Costa Rica, 77-95.

Champourcín, E. de (1991), Poesía a través del tiempo, Barcelona, Anthropos.

CheVAlier, J. y GHEERBRANT, A. (1988), Diccionario de los símbolos, Barcelona, Herder.

CONDE, C. (1938), «Poemas a los niños que mueren en la guerra», Mujeres Libres, 11, s.p. Disponible en: <https://cgt.org.es/wp-content/uploads/2017/10/Mujeres-Libres11_0.pdf $>$.

DÍAZ PARDO, F. (2018), Breve historia de la Generación del 27. Vanguardias españolas, Madrid, Nowtilus.

DíAZ-Casanueva, H. (1975), «Tránsito de Eunice Odio», en Antología, Liscano, J. (ed.), Caracas, Monte Ávila Editores, 9-14.

DIEGO, G. (1927), «La vuelta a la estrofa» [en línea]. Revistas.edaddeplata.org. Disponible en: <http://revistas.edaddeplata.org:8080/cgi-bin_todas/WUV.exe?app=rev>.

DiEGO, G. (1928), «Defensa de la poesía», en Obras completas, VI, Madrid, Alfaguara, 187192.

DURAND, G. (1982), Las estructuras antropológicas de lo imaginario, Madrid, Taurus.

FERNÁNDEZ, P. (1979), Estilística. Estilo-figuras estilísticas-tropos, Madrid, José Porrúa Turanzas.

GARCía LORCA, F. (2013), Poesía completa, Barcelona, Galaxia Gutenberg.

GARCÍA LORCA, F. (2017), «Importancia histórica y artística del primitivo canto andaluz llamado "cante hondo". Conferencia leída en el Centro Artístico de Granada el 19 de febrero de 1922». Disponible en: <http://www.lettere.uniroma1.it/sites/default/ files/673/Importancia\%20hist\%C3\%B3rica \%20y\%20art\%C3\%ADstica\%20del\%20p rimitivo\%20canto\%20Andaluz\%20llamado\%20Cante\%20Jondo.pdf $>$.

GARCíA, M. Á. (2016), Cartografías del compromiso. Vanguardias e ideologías en los poetas del 27, Barcelona, Calambur.

GuILLÉN, N. (1990), Summa poética, Madrid, Cátedra.

HERNÁNDEZ, M. (2000), El hombre y su poesía, Madrid, Cátedra.

LAGO, A. (1997), América en la conciencia española de nuestro tiempo, Madrid, Trotta.

Lama, V. de (1997), Poesía de la Generación del 27. Antología crítica comentada, Madrid, EDAF.

LiSCANO, J. (1975), «Eunice hacia la mañana», en Eunice Odio. Antología. Rescate de una gran poeta, Odio, E., Caracas, Monte Ávila Editores, 27-65.

López-CASAnOva, A. (1994), El texto poético. Teoría y metodología, Madrid, Colegio de España.

MADRIMASD (2018), «Poemas de laboratorio» [en línea]. Madrid, Madri+d, 23.10.2018. Disponible en: <https://www.madrimasd.org/cultura-cientifica/ciencia-cultura/ poesia/poemas-laboratorio>.

MARTínez SAGI, A. M. (2019), La voz sola, Madrid, Fundación Banco Santander.

MONGE, C. F. (1992), Antología crítica de la poesía costarricense, San José, Editorial Universidad de Costa Rica.

MONGE, C. F. (2005), El vanguardismo literario en Costa Rica, Heredia, Editorial Universidad Nacional. 
MUÑOZ, M. Y ACUÑA, K. (en prensa), «La intelectual Eunice Odio ante el relato de la Guerra Civil Española: las trampas del maniqueísmo ideológico», en Centenario de fuego: nuevas aproximaciones a la producción literaria de Eunice Odio en homenaje de su natalicio, Campos, R. y Víquez, A. (eds.), San José, Editorial de la Universidad de Costa Rica.

ODIO, E. (2017a), Eunice Odio: obras completas, I, San José, Editorial Universidad de Costa Rica.

ODIO, E. (2017b), Eunice Odio: obras completas, III, San José, Editorial Universidad de Costa Rica.

Odio, E. (2018), Eunice Odio. Antología poética anotada, Vallbona, R. de y Paldao, C. (comps.), San José, Editorial Costa Rica.

Oliva MEDina, M. (2011), España desde lejos: intelectuales y letras centroamericanos sobre la guerra civil española (1931-1953), San José, Editorial de la Universidad Estatal a Distancia.

ORTEGA Y GASSET. J. (1999), La deshumanización del arte, Madrid, Austral.

ORTEGA, J. (1986), «El gitano y el negro en la poesía de poesía de García Lorca», Cuadernos Hispanoamericanos, I(433-434), 145-168.

ORTUÑO, R. (2014), Mitos cristianos en la poesía del 27, Londres, The Modern Humanities Research Association.

Oviedo, J. (2001), Historia de la literatura hispanoamericana. Posmodernismo, vanguardia, regionalismo, Madrid, Alianza Editorial.

PleiteZ, T. (2012), «Arraigo onírico. Tras el perfume surrealista de la joven Eunice Odio», Cuadernos Inter.C.A.mbio, 9(10), 237-264.

RojAs Mix, M. (1997), Los cien nombres de América: Eso que descubrió Colón, San José, Editorial Universidad de Costa Rica.

ROJAs, M. y OVARES, F. (2018), 100 años de literatura costarricense, San José, Editorial Costa Rica, Editorial Universidad de Costa Rica.

SALINAS, P. (1983), «La valía de la tradición», en Ensayos completos, I, Madrid, Taurus, 363-374.

SANTOS SILVA, L. (2001), «Los elementos terrestres o el materialismo crítico», en La palabra innumerable: Eunice Odio ante la crítica, Chen Sham, J. y Vallbona, R. de (eds.), San José, Editorial Universidad de Costa Rica, 65-76.

VAllbONA, R. de (1980), La obra en prosa de Eunice Odio, San José, Editorial Costa Rica.

VALlBONA, R. de (2001), «Eunice Odio ante la crítica», en La palabra innumerable: Eunice Odio ante la crítica, Chen Sham, J. y Vallbona, R. de (eds.), San José, Editorial Universidad de Costa Rica, 21-40.

VERES, L. (2002), «Nicolás Guillén y el período vanguardista en América Latina», CiberLetras: revista de crítica literaria y de cultura, 7. Disponible en: $<$ http://www.lehman.cuny.edu/ciberletras/v07/veres.html $>$.

WiNERUDA (s.f.), «Poesía de Lucía Sánchez Saornil» [en línea]. Winerudaliteratura.blogspot.com, 31 de marzo 2017. Disponible en: <https://winerudaliteratura.blogspot.com/2017/03/poesia-de-lucia-sanchez-saornil.html>. 